\title{
Bacterial diversity in relatively pristine and anthropogenically-influenced mangrove ecosystems (Goa, India)
}

\author{
Sheryl Oliveira Fernandes ${ }^{1}$, David L. Kirchman ${ }^{2}$, Valérie D. Michotey ${ }^{3,4}$, \\ Patricia C. Bonin ${ }^{3,4}$, P.A. LokaBharathi ${ }^{1}$ \\ ${ }^{1}$ Biological Oceanography Division, National Institute of Oceanography, Dona Paula, Goa, India. \\ ${ }^{2}$ School of Marine Science and Policy, University of Delaware, Lewes, DE, USA. \\ ${ }^{3}$ Mediterranean Institute of Oceanography, Aix-Marseille University, Marseille, France. \\ ${ }^{4}$ Aix Marseille Université, MIO UM 110, 13288, Marseille, France.
}

Submitted: September 11, 2013; Approved: June 6, 2014.

\begin{abstract}
To appreciate differences in benthic bacterial community composition at the relatively pristine Tuvem and the anthropogenically-influenced Divar mangrove ecosystems in Goa, India, parallel tag sequencing of the V6 region of $16 \mathrm{~S}$ rDNA was carried out. We hypothesize that availability of extraneously-derived anthropogenic substrates could act as a stimulatant but not a deterrent to promote higher bacterial diversity at Divar. Our observations revealed that the phylum Proteobacteria was dominant at both locations comprising $43-46 \%$ of total tags. The Tuvem ecosystem was characterized by an abundance of members belonging to the class Deltaproteobacteria (21\%), 2100 phylotypes and 1561 operational taxonomic units (OTUs) sharing $>97 \%$ similarity. At Divar, the Gammaproteobacteria were $\sim 2 \mathrm{x}$ higher $(17 \%)$ than at Tuvem. A more diverse bacterial community with $>3300$ phylotypes and $>2000$ OTUs mostly belonging to Gammaproteobacteria and a significantly higher DNT $(\mathrm{n}=9, \mathrm{p}<0.001, \mathrm{df}=1)$ were recorded at Divar. These findings suggest that the quantity and quality of pollutants at Divar are perhaps still at a level to maintain high diversity. Using this technique we could show higher diversity at Divar with the possibility of Gammaproteobacteria contributing to modulating excess nitrate.
\end{abstract}

Key words: bacteria, denitrification, diversity, mangroves, sediments.

\section{Introduction}

Mangroves constitute nearly $75 \%$ of tidal vegetation in tropical regions (Alongi et al., 1989). The proximity of these coastal wetlands to human inhabitation, aquaculture farms, waste discharge from industrial units and domestic sewage release make them vulnerable to high nutrient inputs especially inorganic nitrogen $(\mathrm{N})$. Microbial communities in mangrove sediments play an important role in the biogeochemical cycles of coastal ecosystems (Thorsten and José, 2001). Anaerobic conditions and substrate availability in organic C-rich mangrove sediments (Krishnan and LokaBharathi, 2009) favour alternate respiratory pathways like denitrification and sulfate reduction. Recently, it has been shown that bacterially-mediated benthic denitrifica- tion effectively reduces $\mathrm{N}$ load in an anthropogenicallyinfluenced tropical mangrove ecosystem of Goa, India (Fernandes and LokaBharathi, 2011). However, little is known about the microbial communities inhabiting these regions.

In-depth analysis of prokaryotic communities is crucial in understanding ecosystem functioning. So far, few culture-independent studies have been carried out to assess the taxonomic diversity of bacteria in mangrove sediments (Liang et al., 2007; Marcial Gomes et al., 2008; Sjöling et al., 2005). The sequences recovered in these studies revealed the dominance of Proteobacteria and the presence of all five sub-divisions within this class. As these phylogenetic studies used traditional clone library and sequencing approaches, only a small fraction of the mangrove bacterial communities could be sampled. New technology, such as 
pyrosequencing of hypervariable regions of the 16S rRNA gene, is a cost-effective and a better alternative to examine the phylogenetic diversity of microbial populations (Huse et al., 2008; Schwarz et al., 2007). This technology has been applied to the water column of the oceans (Andersson et al., 2010; Huber et al., 2007; Kirchman et al., 2010; Sogin et al., 2006), soils (Roesch et al., 2007) and more recently to marine sediments (Chariton et al., 2010; Kim et al., 2008). To our knowledge, very few studies have used the pyrosequencing approach to examine the prokaryotic diversity in mangrove sediments.

Though physiology cannot be assumed from phylogenetic analysis (Kim et al., 2008), bacterial diversity data could be useful for understanding the ecological roles that microbes may play in the environment. Hence, the present study was carried out to gain an insight into the taxonomic diversity of bacteria in two tropical mangrove systems of Goa, India using the pyrosequencing approach. The relatively pristine site Tuvem was compared to Divar which is influenced by extraneous nutrient input. The Divar mangrove ecosystem lies along the Mandovi estuary. This estuary receives a considerable supply of inorganic nitrogenous nutrients from various sources such as mining wastes (De Souza, 1999), land runoff (Sardessai and Sundar, 2007) and sewage effluents (Ansari et al., 1986). We hypothesize that these extraneously-derived substrates at Divar could support higher bacterial diversity. Our observations revealed higher bacterial diversity at Divar suggesting that the levels of pollutants have not reached a limiting level. Higher sequence clusters of class Gammaproteobacteria and denitrification activity (DNT) were recorded at Divar which is suggestive of their important ecological role in controlling the levels of excess nitrate in the ecosystem through denitrification.

\section{Materials and Methods}

\section{Study area and sampling}

Investigations were carried out at mangrove forests located along the Mandovi and Chapora rivers in Goa, west coast of India (Fernandes et al., 2010). One site was at

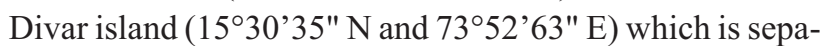
rated from the mainland by the Mandovi estuary. The adjoining Mandovi estuary is used heavily for transportation of iron ore from mines located upstream. These iron ore beneficiation plants situated on the riverbank, discharge effluents directly into the estuary. This discharge contains high quantities $\left(\sim 8-10 \mathrm{Mg}\right.$ month $\left.^{-1}\right)$ of $\mathrm{NH}_{4} \mathrm{NO}_{3}$ used in ferromanganese mining operations (De Souza, 1999). The second site was located at Tuvem (15'39'94" $\mathrm{N}$ and $73^{\circ} 47^{\prime} 65^{\prime \prime}$ E) along the river Chapora. This ecosystem is comparatively less influenced by anthropogenic activities and considered as relatively pristine (Krishnan et al., 2007).

The Mandovi estuary receives high extraneous nitrate input during the monsoon (Divya et al., 2009). Sampling was carried out at low tide during this season (September, 2008). A total of 12 cores were collected from each site which were used as follows:

(i) Three cores were collected using PVC push cores ( $7.5 \mathrm{~cm}$ inner diameter, $20 \mathrm{~cm}$ length) and capped at both ends. They were transferred to a plastic tray for transportation to the laboratory under ambient temperature. The variation in physical parameters was measured on arrival to the laboratory i.e. within $1 \mathrm{~h}$ of sampling.

(ii) Six cores of dimensions described above were collected for chemical and microbiological analyses. These were transported to the laboratory in an ice box. On arrival, the cores were maintained at $4{ }^{\circ} \mathrm{C}$ until analysis.

(iii) Three sediment cores were collected for molecular biology analysis using pre-cut (open-ended), pre-sterilized $50 \mathrm{~mL}$ syringe cores. The contents were transferred to clean plastic bags, each of which was sealed with a rubber band. The cores were immediately preserved in a liquid nitrogen containing cryocan for transportation to the laboratory. On arrival, the samples were stored at $-20{ }^{\circ} \mathrm{C}$ until analysis.

Earlier observations at Tuvem and Divar have shown have shown highest DNT to occur at the surface $(0-2 \mathrm{~cm})$ of mangrove sediments (Fernandes et al., 2010; Fernandes and LokaBharathi, 2011). Hence, analyses of all parameters in the present manuscript have been restricted to the surficial sediments.

\section{Physico-chemical analysis}

Hydrogen ion concentration $(\mathrm{pH})$ in the surficial sediments was measured using an Orion 4-Star Plus benchtop pH/ISE meter (Thermo Fisher Scientific Inc., Waltham, MA). Sediment oxidation-reduction potential (Eh) was measured using an Orion platinum redox in combination with an $\mathrm{Ag} / \mathrm{AgCl}_{2}$ reference electrode (Thermo Fisher Scientific Inc.).

For nutrient analyses, the top two centimeters of each core was sectioned and transferred to $100 \mathrm{~mL}$ of sterile saline $\left(8.5 \mathrm{~g} \mathrm{~L}^{-1} \mathrm{NaCl}\right)$. The contents were gently homogenized using a glass rod. The resultant slurry was centrifuged at $4{ }^{\circ} \mathrm{C}$ for $10 \mathrm{~min}$ at $5000 \mathrm{rpm}$. A low spin speed was maintained during centrifugation to ensure minimal change in nutrient concentrations due to lysis of benthic infauna. The supernatant was filtered through a $0.2 \mu \mathrm{m}$ filter. Nitrite, ammonium and nitrate were measured colorimetrically $\left( \pm 0.01 \mu \mathrm{mol} \mathrm{L}{ }^{-1}\right.$ ) according to standard methods (Bendschneider and Robinson, 1952; Koroleff, 1969; Wood et al., 1967). Weight of the sediment used in the extraction was estimated by drying the sediment in a hot air oven at $60{ }^{\circ} \mathrm{C}$ for $48 \mathrm{~h}$.

Surficial sediment samples for analysis of total organic carbon (TOC) were dried in a hot air oven at $60^{\circ} \mathrm{C}$ for $48 \mathrm{~h}$. The TOC in the sediment was determined by the wet oxidation method (El Wakeel and Riley, 1957) with a precision of $0.01 \%$. 


\section{Total bacterial counts}

Sediment cores were sectioned from surface to $2 \mathrm{~cm}$. Sub-samples of $\approx 5 \mathrm{~g}$ wet weight sediment were extruded using syringe cores. The sub-samples were transferred to $45 \mathrm{~mL}$ of filter sterilized full strength seawater $\left(10^{-1}\right.$ dilution). Tween $80(50 \mu \mathrm{L})$ was added and the mixture was sonicated at $40 \mathrm{mHz}$ for $15 \mathrm{~s}$. The sub-samples were diluted with filter sterilized seawater and fixed with buffered formalin ( $2 \%$ final concentration).

Enumeration of total bacteria was carried out by epifluorescence microscopy (Hobbie et al., 1977). A subsample was stained with acridine orange (final concentration $0.01 \% \mathrm{w} / \mathrm{v}$ ), incubated for $2 \mathrm{~min}$ and then filtered through $0.2 \mu \mathrm{m}$ black Isopore polycarbonate filters (Millipore). Bacterial cells were counted using a Nikon $50 \mathrm{i}$ epifluorescence microscope equipped with a 100X oil immersion objective. Cells were counted from 10-100 microscopic fields. Total bacterial counts were expressed as cells $\mathrm{g}^{-1}$ (dry sediment).

\section{Denitrification activity}

Denitrification rates were measured using sediment slurries by the acetylene inhibition technique based on the inhibition of the conversion of $\mathrm{N}_{2} \mathrm{O}$ to $\mathrm{N}_{2}$ (Sørensen, 1978). About $1 \mathrm{~cm}^{3}$ sediment from $0-2 \mathrm{~cm}$ was extruded using a syringe core and transferred aseptically to sterile $20 \mathrm{~mL}$ headspace vials. Three $\mathrm{mL}$ of sterilized ambient sea water from the sampling site containing $4.3 \mu \mathrm{mol} \mathrm{NO}{ }_{3}^{-}-\mathrm{N} \mathrm{L}^{-1}$ was added to the sediment. No additional carbon or nitrate was amended to the seawater. The vials were capped with butyl stoppers and the slurry was briefly vortexed for $5 \mathrm{sec}$. The vials were purged with high purity $\mathrm{N}_{2}$ for 10 min to induce anaerobic conditions. The headspace over these slurries was amended with acetylene at $20 \mathrm{kPa}$ (Bonin et al., 2002) and the tubes were briefly vortexed. Triplicates were maintained and the vials were then incubated in the dark for 0 , $0.5,1.0,1.5,2.0,2.5,3.0 \mathrm{~h}$. At the end of the incubation period, bacterial activity in all incubations was terminated using $0.1 \mathrm{~mL}$ of $1 \mathrm{~mol} \mathrm{~L}^{-1} \mathrm{HgCl}_{2}$ solution.

Nitrous oxide in the headspace was analyzed using a Shimadzu 2010 gas chromatograph fitted with a electron capture detector and Porapak Q column (1/8" SS column, $3.05 \mathrm{~m}$ length, $80 / 100 \mathrm{mesh})$. The oven and detector temperatures were $40{ }^{\circ} \mathrm{C}$ and $300{ }^{\circ} \mathrm{C}$, respectively. High purity nitrogen at a flow rate of $35 \mathrm{~mL} \mathrm{~min}^{-1}$ was used as a carrier gas. The gas chromatograph was calibrated using a secondary standard $44 \pm 0.38 \mathrm{nmol} \mathrm{L}^{-1} \mathrm{~N}_{2} \mathrm{O}$ in nitrogen (National Physical Laboratory, New Delhi). Denitrification activity was calculated based on the linear accumulation of $\mathrm{N}_{2} \mathrm{O}$ over time (Tiedje, 1982). The solubility coefficients of $\mathrm{N}_{2} \mathrm{O}$ were used to correct for dissolved $\mathrm{N}_{2} \mathrm{O}$ (Weiss and Price, 1980). Sediment used in each microcosm was filtered through a laboratory grade filter paper and dried at $60{ }^{\circ} \mathrm{C}$ for approximately $48 \mathrm{~h}$ and weighed. Denitrification rate was expressed as nmol $\mathrm{N}_{2} \mathrm{O} \mathrm{g}^{-1} \mathrm{~h}^{-1}$ of dry sediment. Analysis of variance (ANOVA) in Analysis tool pack (Microsoft Excel) was used to assess significant difference in denitrification activity between both the locations.

\section{DNA extraction, high-throughput pyrosequencing and data analyses}

Genomic DNA was extracted from $0.25 \mathrm{~g}$ (dry weight) sediment from each of the 3 cores collected. The Mo Bio PowerSoil DNA isolation kit (Mo Bio Laboratories, California) was used to extract the DNA according to the manufacturer's protocol. Though analyses in triplicate would have been ideal, analysis was restricted to one in this study as it was a preliminary assessment to draw a first order comparison. The DNA of single sample was concentrated and used for pyrosequencing analysis while the rest were used for other down-stream applications. The hypervariable region of 16S rRNA gene (BV6-rRNA tags) were amplified, subjected to high-throughput pyrosequencing and the sequence reads were then trimmed (Sogin et al., 2006; Huber et al., 2007). Pyrosequencing error rates were minimized (Huse et al., 2007).

The 454 tags (reads) served as query to identify its closest match in a reference database (V6RefDB) containing $\approx 40,000$ unique V6 sequences (Sogin et al., 2006). Singletons were removed from the dataset before further analyses. Sequence characteristics like average length and tag aggregates were estimated using $R$ package (R Development Core Team, 2007). Multiple sequence alignment was done using ClustalX 1.83. Distance matrices were calculated using DNAdist from PHYLIP 3.69 (Felsenstein, 2005). DOTUR (Schloss and Handelsman, 2005) was used for clustering tags that ranged from unique sequences showing no variation to $5 \%$ dissimilarity. These clusters served as operational taxonomic units (OTUs) for generating rarefaction curves and for calculating two indices of diversity- Chaol (Chao, 1987) and ACE (abundance-based coverage estimator (Chao and Lee, 1992). The OTU overlap between samples was plotted using the Venn Diagram Plotter (Pacific Northwest National Laboratory, Department of Energy). Information on primers is available at the VAMPS site (http://vamps.mbl.edu/). Tag sequences used in this study have been archived under ICM_ICR_Bv6-ICoMM Cooperative Run and can be accessed using the link http://vampsarchive.mbl.edu/vamps/combined/combined.php. The dataset ID no. for sample from Divar is ICR_0003_2008_09_05 while for Tuvem is ICR_0004_2008_09_05.

\section{Results}

\section{Sediment characterization}

At the time of sampling, precipitation due to the south-west monsoon resulted in fresh water conditions at 
the sampling locations as observed from salinity values of $\leq 1 \mathrm{psu}$ (Table 1). Though $\mathrm{pH}$ was marginally higher at Tuvem, reducing conditions were more intense at this location with up to $-202 \pm 42 \mathrm{mV}$ as compared to a redox potential of $55.5 \pm 2.3 \mathrm{mV}$ at Divar (Table 1). However, inorganic nitrogenous compounds $\left(\mathrm{NH}_{4}{ }^{+}, \mathrm{NO}_{3}{ }^{-}\right.$and $\left.\mathrm{NO}_{2}{ }^{-}\right)$ and organic carbon content were higher at Divar than at the relatively pristine Tuvem. Denitrification activity at Divar occurred at a rate of up to $3.17( \pm 0.99) \mathrm{nmol} \mathrm{N} \mathrm{O} \mathrm{g} \mathrm{g}^{-1} \mathrm{~h}^{-1}$ which was significantly higher $(\mathrm{n}=9, \mathrm{p}<0.001, \mathrm{df}=1)$ as compared to Tuvem. The mangrove sediments harboured up to $10^{10}$ bacterial cells $\mathrm{g}^{-1}$; the Divar sediments had marginally higher abundance $\left(2.67( \pm 1.76) \times 10^{10}\right.$ cells $\left.\mathrm{g}^{-1}\right)$ than at Tuvem $\left(1.45( \pm 0.20) \times 10^{10}\right.$ cells g $\left.{ }^{-1}\right)$.

\section{Bacterial diversity in mangrove sediments}

More than 34,000 bacterial V6 amplicons were sequenced from the two sites (Table 2). The average read length of the sequences from both sites was $60.7 \pm 2.6 \mathrm{bp}$. Taxonomic analysis revealed differences in community composition between the two sites. The phylum Proteobacteria was the most dominant, contributing 43 and $46 \%$ of total V6 tags at Tuvem and Divar respectively (Figure 1). About 22 and $18 \%$ of the bacterial tag sequences at Tuvem and Divar respectively have not been identified to the class level (Figure 2). Deltaproteobacteria was the next most abundant class at Tuvem comprising $\sim 21 \%$ of the total tag sequences while at Divar their abundance was 15\% (Figure 2). Other important classes recorded at the locations were Actinobacteria, Gammaproteobacteria and Alphaproteobacteria. Within class Deltaproteobacteria, up to $53 \%$ tags comprised of order Desulfobacterales (Figure 3). Some of the other deltaproteobacterial sequences found at these locations belonged to the orders Desulfuromonadales, Myxococcales and Synthrophobacterales. At Divar, the Gammaproteobacteria comprised $36 \%$ of the

Table 1 - Environmental parameters at sampling locations.

\begin{tabular}{|c|c|c|}
\hline & Tuvem & Divar \\
\hline Temp $\left({ }^{\circ} \mathrm{C}\right)$ & $27.7( \pm 0.1)$ & $28.0( \pm 0.1)$ \\
\hline Salinity (psu) & 0 & 1 \\
\hline $\mathrm{pH}$ & $6.65( \pm 0.01)$ & $6.29( \pm 0.03)$ \\
\hline $\mathrm{Eh}(\mathrm{mV})$ & $-202.2( \pm 41.86)$ & $55.5( \pm 2.26)$ \\
\hline $\mathrm{NH}_{4}{ }^{+}-\mathrm{N}\left(\mu \mathrm{mol} \mathrm{L}{ }^{-1}\right)$ & $2.58( \pm 0.69)$ & $11.78( \pm 0.44)$ \\
\hline $\mathrm{NO}_{2}^{-}-\mathrm{N}\left(\mu \mathrm{mol} \mathrm{L}^{-1}\right)$ & $3.37( \pm 0.20)$ & $5.85( \pm 0.28)$ \\
\hline $\mathrm{NO}_{3}^{-}-\mathrm{N}\left(\mu \mathrm{mol} \mathrm{L}{ }^{-1}\right)$ & $3.01( \pm 0.11)$ & $5.52( \pm 0.10)$ \\
\hline TOC (\%) & $1.05( \pm 0.44)$ & $1.98( \pm 0.96)$ \\
\hline $\begin{array}{l}\text { Total bacterial cells } \\
\left(\times 10^{10} \text { cells g }^{-1}\right)\end{array}$ & $1.45( \pm 0.20)$ & $2.67( \pm 1.76)$ \\
\hline $\begin{array}{l}\text { Denitrification activity } \\
\left(\mathrm{nmol} \mathrm{N}_{2} \mathrm{O} \mathrm{g}^{-1} \mathrm{~h}^{-1}\right)\end{array}$ & $1.95( \pm 0.85)$ & $3.17( \pm 0.99)$ \\
\hline
\end{tabular}

Proteobacteria followed by Deltaproteobacteria (33\%) and Alphaproteobacteria (22\%). Among the Gammaproteobacteria, $>60 \%$ of the tags remained unidentified to the order level (Figure 4). The next most abundant order was Chromatiales. About $76 \%$ of the tags at both the sites could not been identified to the genus level.

Using the furthest neighbor assignment algorithm implemented in DOTUR, more than 2600 unique V6 tag sequences were placed in 1561 operational taxonomic units (OTUs) that were $<3 \%$ dissimilar at Tuvem. Nonparametric statistical analysis (ACE) predicted the presence of 2166 OTUs at Tuvem. At Divar, 24\% of the total trimmed sequences were unique with 2198 OTUs while the predicted OTUs were estimated to be $\sim 3300$. Similarly, species richness estimated by the Chaol estimator was higher at Divar than Tuvem (Table 1). Rarefaction curves did not reach a maximum and continued to increase with increasing sample size (Figure 5), indicating that the complete diversity at both sites had not been sampled. Phylogenetic classification of the twenty most abundant clusters ( $\geq 97 \%$ similarity) at Tuvem showed that they belonged to the class Deltaproteobacteria while at Divar, sequences from taxonomic groups within the Gammaproteobacteria were dominant. Large portion of the bacterial community were site specific (Figure 6). Only about 550 of the OTUs were common between both sites with $35 \%$ representation from Tuvem and 25\% from Divar.

\section{Discussion}

Earlier investigations at Tuvem and Divar have focussed on examining the occurrence of denitrification, associated processes and functional diversity of denitrifiers (Fernandes et al., 2010; Fernandes et al., 2012). The major denitrifying communities at these locations belong to uncultured microorganisms clustering within Proteobacteria (Fernandes et al., 2012). As denitrification is widespread in many genera, it would be interesting to obtain a census of bacteria in the area. High throughput pyrosequencing permits culture-independent analysis of bacteria in soil DNA extracts (Roesch et al., 2007). Under the aegis of the International Census of marine microbes (ICoMM), this technique was used to obtain an initial appreciation of the bacterial diversity in relatively pristine and anthropogenically-influenced mangrove ecosystems of Goa, India.

Previous studies have shown predominant bacterial phylotypes in mangrove sediments to cluster within Proteobacteria, Bacteroidetes, Gemmatimonadetes, Actinobacteria and Firmicutes (Zhang et al., 2009). Application of the pyrosequencing technology revealed that sediments at Tuvem and Divar harbour all major sediment bacterial groups affiliated with the phyla Proteobacteria, Bacteroidetes, Firmicutes, Chloroflexi, Planctomycetes, and Actinobacteria. This study also revealed the existence of bacteria belonging to other phyla like Acidobacteria, Gem- 
Table 2 - Sequencing information and diversity estimates for all bacteria at Tuvem and Divar.

\begin{tabular}{lcc}
\hline & Tuvem & Divar \\
\hline DNA recovered from 0.25 g sediment (ng/ $\mu \mathrm{L})$ & 10.8 & 15.2 \\
Total number of bacterial V6 tag sequences & 12954 & 21433 \\
Total number of trimmed bacterial V6 tag sequences ${ }^{*}$ & 8030 & 15326 \\
Total number of unique sequences & 2661 & 3707 \\
Total OTUs at 3\% difference & 1561 & 2198 \\
Chao1 estimator of richness at 3\% difference (min, max) & $1988(1914,2076)$ & $3092(2968,3237)$ \\
ACE estimator of richness at 3\% difference (min, max) & $2166(2136,2196)$ & $3342(3261,3429)$ \\
\hline
\end{tabular}

* After removal of singletons.

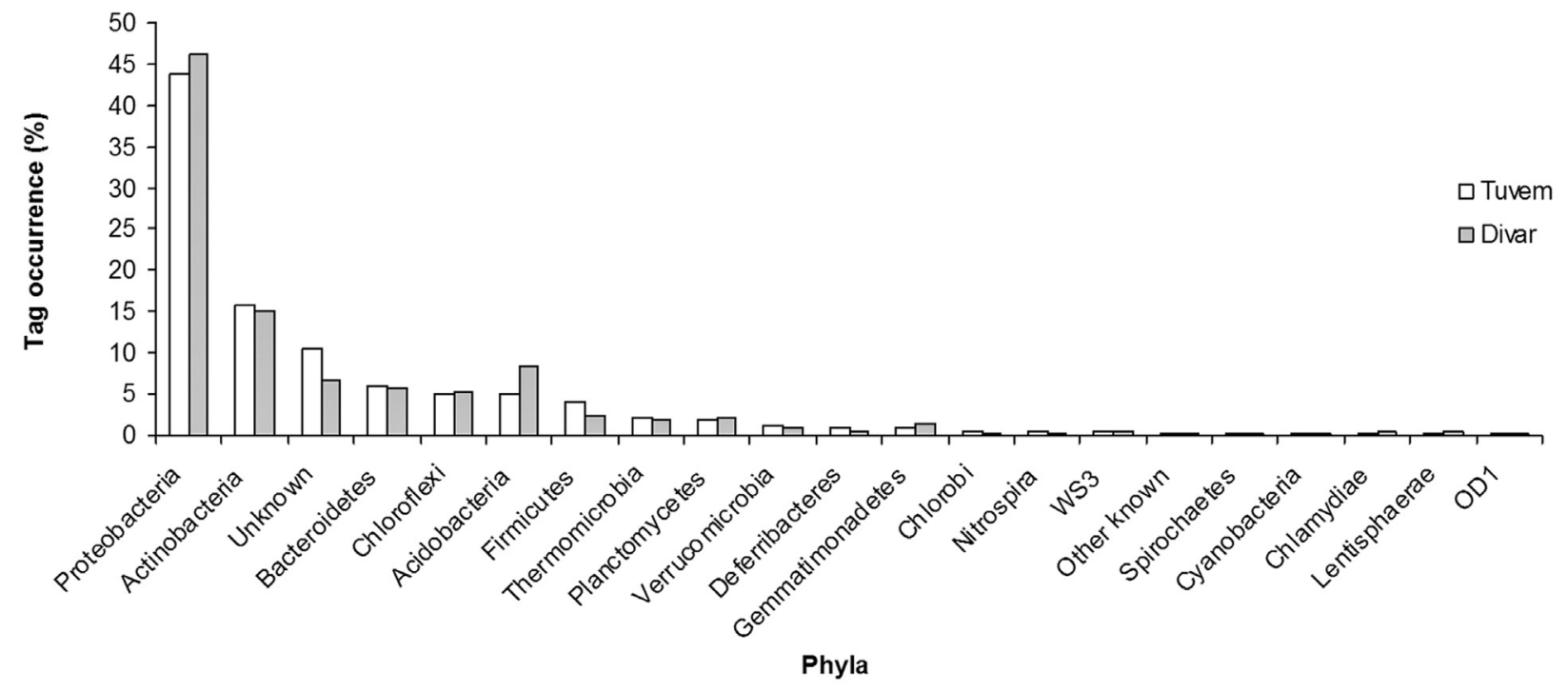

Figure 1 - Phylum level distribution of tag sequences at Tuvem $(\mathrm{n}=8030$ tags $)$ and Divar $(\mathrm{n}=15326$ tags).

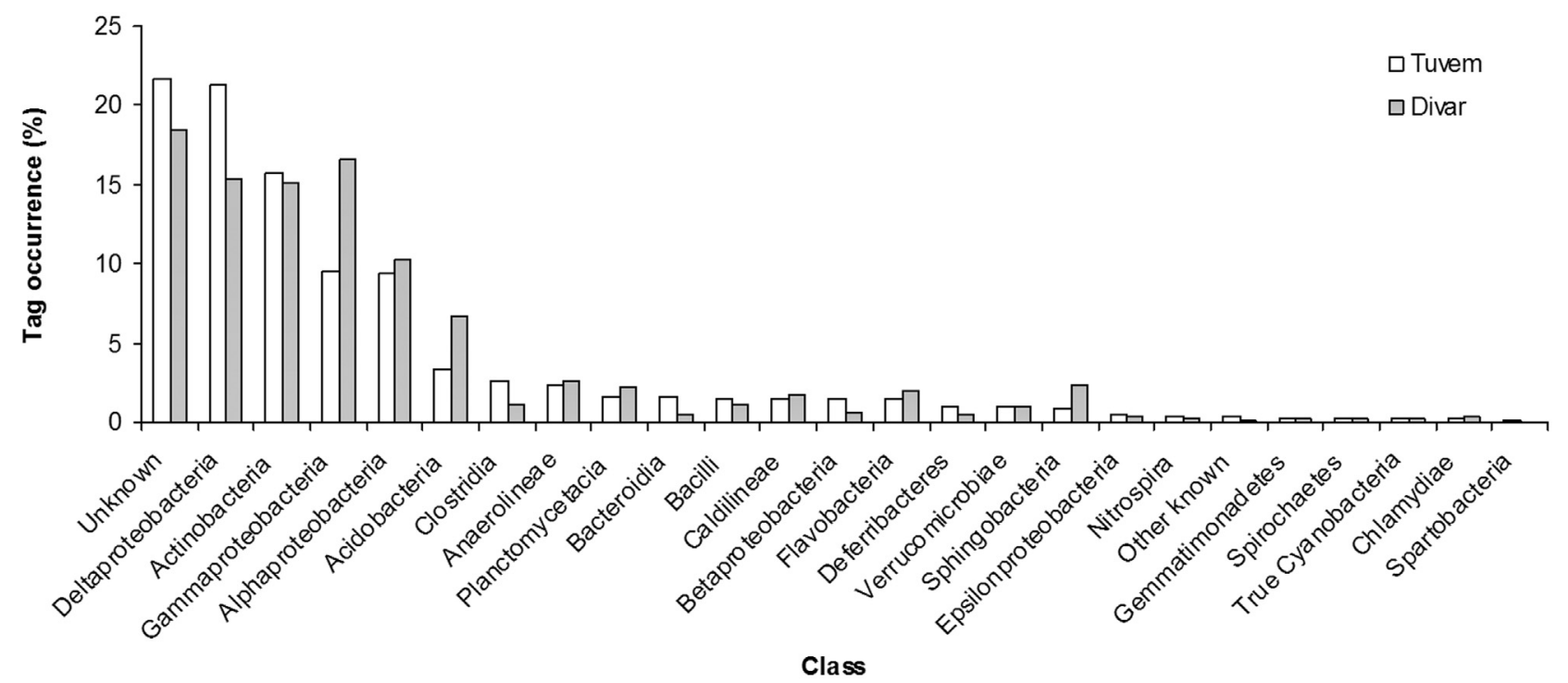

Figure 2 - Class level phylogenetic classification of bacterial communities at Tuvem ( $\mathrm{n}=8030$ tags) and Divar ( $\mathrm{n}=15326$ tags). Tags of known classes that occurred at an abundance of $<0.1 \%$ have been grouped in the "Other known" category. 
matimonadetes and members of the candidate divisions OD1 and WS3 in mangrove sediments. The phylum Gemmatimonadetes has been found earlier in systems with high nutrient input (Li et al., 2006). The candidate divisions OD1 and WS3 have been reported to occur in anoxic sediments and their occurrence has been attributed to sulfur cycling (Kirkpatrick et al., 2006). Thus, their occurrence in mangrove sediments is suggestive of their participation in sulfate reduction.

Consistent with previous studies of marine sediments (Bowman et al., 2005; Zhao and Zeng, 2008), our results too have shown Proteobacteria to be the most abundant in mangroves. As in Divar, the Proteobacteria at Tuvem constituted $>40 \%$ of the total tags. As determined by tag abun- dance, the proteobacterial community at Tuvem was dominated by members of the class Deltaproteobacteria, mainly members of the order Desulfobacterales. Dos Santos et al. (2011) have also reported higher occurrence of Deltaproteobacteria in pristine mangrove sediments. Earlier studies by LokaBharathi et al. (1991) have reported their occurrence in mangrove swamps of the Zuari estuarine system in Goa. At Tuvem, the redox-potential of the sediments is $\sim-200 \mathrm{mV}$ implying that the benthic environment is largely anaerobic, more so than at Divar. Anoxic environments are known to be dominated by Deltaproteobacteria (Schwarz et al., 2007). This class of bacteria have been reported to occur in coastal (Paisse et al., 2008; Zhang et al., 2008), continental shelf (Hunter et al., 2006) as well

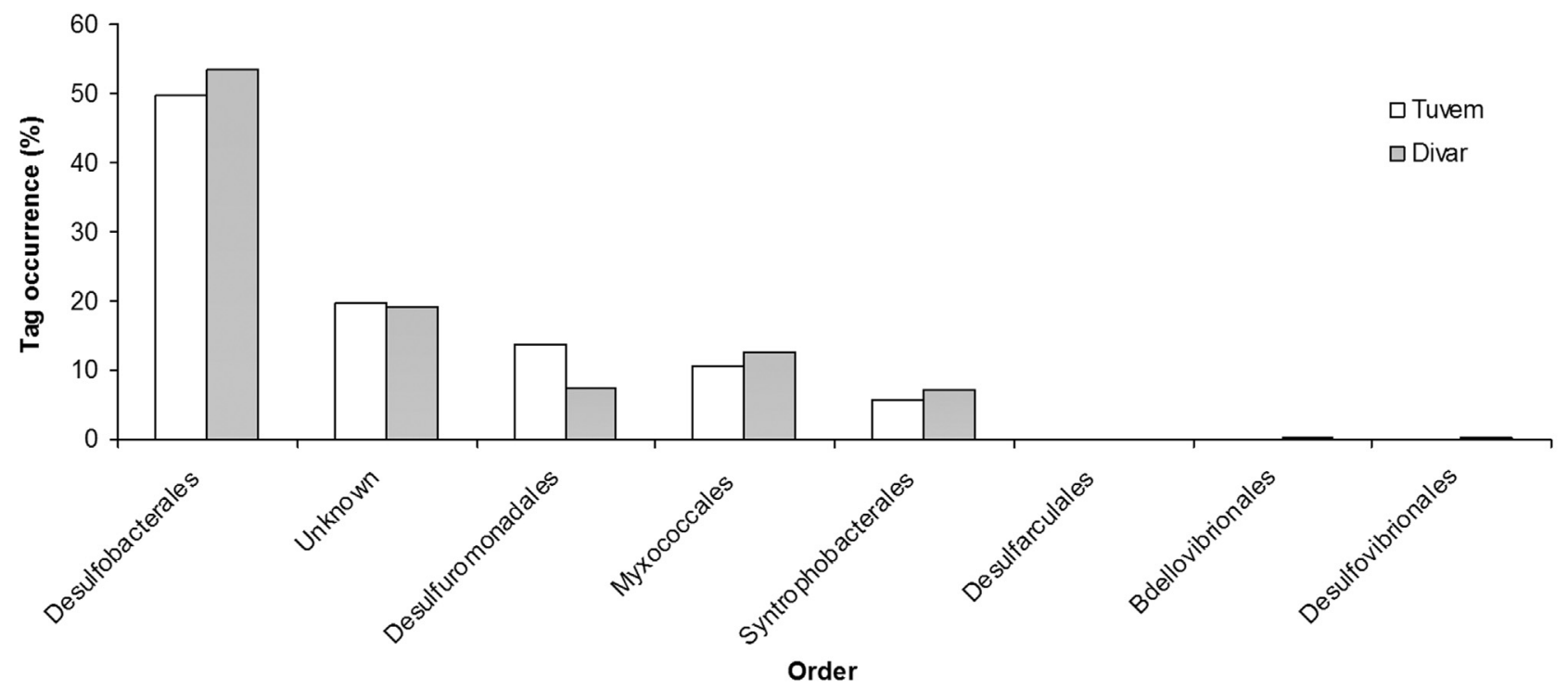

Figure 3 - Order level phylogenetic classification of Deltaproteobacteria at Tuvem $(\mathrm{n}=1712$ deltaproteobacterial tags) and Divar $(\mathrm{n}=2357)$.

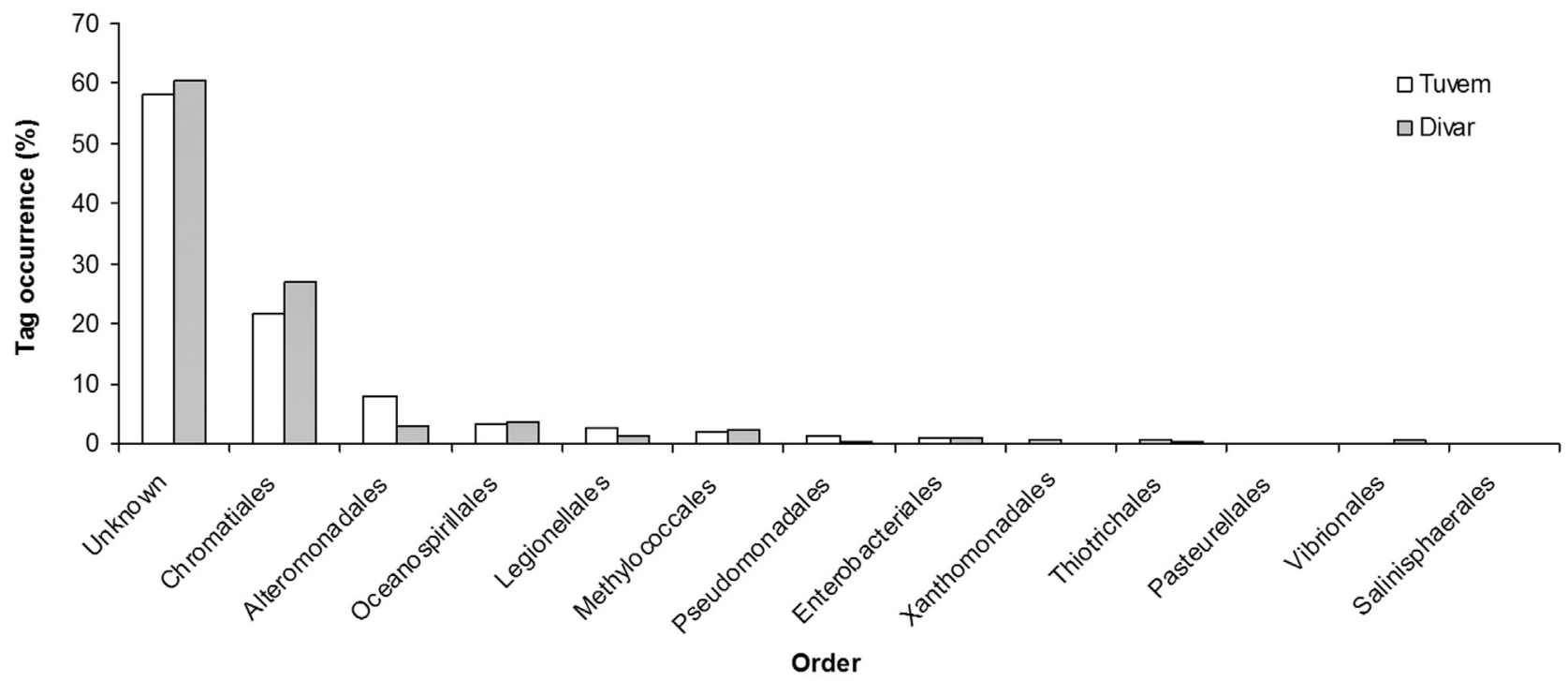

Figure 4 - Order level phylogenetic classification of Gammaproteobacteria at Tuvem ( $\mathrm{n}=762$ gammaproteobacterial tags) and Divar $(\mathrm{n}=2542)$. 


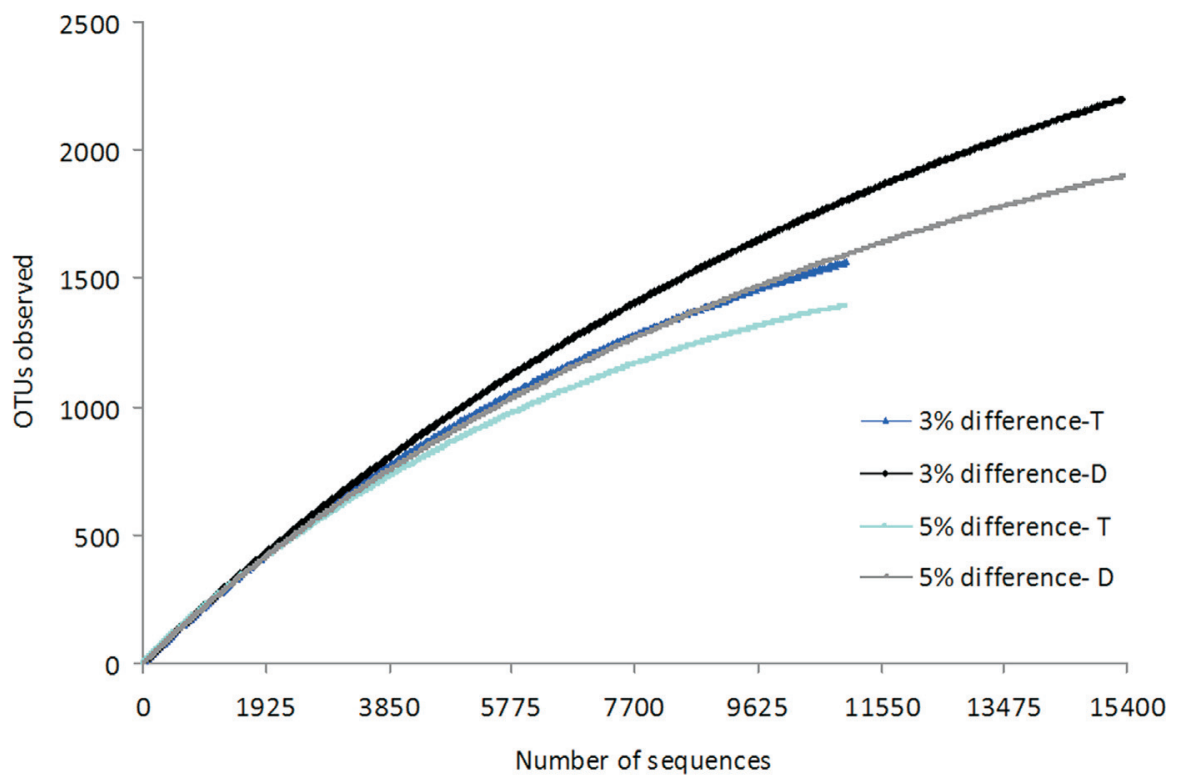

Figure 5 - Rarefaction curves based on 95 and 97\% sequence similarity of sediment bacterial community at Tuvem (T) and Divar (D).

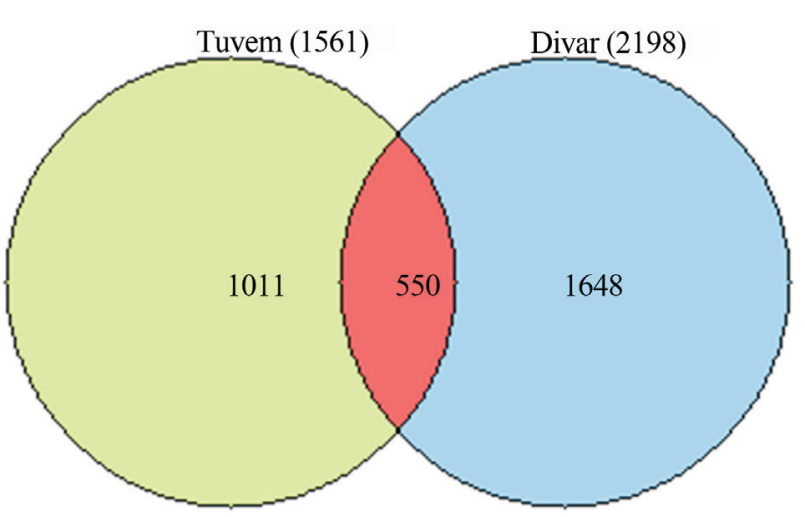

Figure 6 - Venn diagram showing overlap of operational taxonomic units (OTUs) at Tuvem $(\mathrm{n}=1561)$ and Divar $(\mathrm{n}=2198)$. The OTUs represent clusters with $97 \%$ sequence similarity. The numbers in the figure indicates the OTUs.

as cold-seep sediments (Reed et al., 2009). Bacteria belonging to the order Desulfobacterales have been implicated to be involved in sulfur cycling (Vrionis et al., 2005) in particular sulfate reduction (Reed et al., 2009). At Tuvem and Divar, sulfate-reduction has been reported to occur by Attri et al. (2011). It is possible that Deltaproteobacteria in this anoxic habitat not only participate in sulfur cycling but also prevent accumulation of metals (Attri et $a l ., 2011)$ and inorganic nitrogenous compounds by obtaining energy from the reduction of $\mathrm{Fe}(\mathrm{III}), \mathrm{Mn}(\mathrm{IV})$ and nitrate (Greene et al., 2009).

Members of the phylum Actinobacteria are ubiquitous in estuarine and oceanic environments. Nearly $15 \%$ of the sequences recorded at Tuvem and Divar belonged to representatives of the phylum Actinobacteria making it the next most abundant phylum following Proteobacteria. Many Actinobacteria are of economic importance (Ward and Bora, 2006) as they are a source of antibiotics (Adinarayana et al., 2006; Ellaiah and Zeeck, 2006; Kim et al., 2006; Manivasagan et al., 2009). Like Deltaproteobacteria, they play multiple roles in the environment that include degradation of cellulose (Pankratov et al., 2006), hydrocarbons (Harwati et al., 2007), metal oxidation (Bryan and Johnson, 2008; Johnson et al., 2009), and nitrate reduction (Van Keulen et al., 2005). The presence and activity of Actinobacteria in these sediments could thus be vital in altering the benthic chemistry.

The bacterial community at the anthropogenicallyinfluenced Divar was relatively more diverse than at Tuvem. The Divar community had $\sim 3300$ phylotypes which is an order of magnitude higher than previously reported in marine sediments (Zhang et al., 2008). Bacterial diversity can be lower in stressed environments, for example in areas prone to heavy metals (Hu et al., 2007) or hydrocarbon contamination (Greer, 2010). The Divar ecosystem receives high inputs of anthropogenicallyderived organic and inorganic material. Consequently, availability of a wide variety of substrates could result in high taxonomic and metabolic diversity. Deltaproteobacteria were the predominant OTU clusters at Tuvem whereas at Divar, OTUs belonging to the Gammaproteobacteria were dominant. Molecular investigations in a Chinese mangrove ecosystem (Liang et al., 2007) showed that the Gammaproteobacteria-affiliated sequences constituted the largest portion of their clone library. The Gammaproteobacteria are active mediators of the N, S and C cycles. Some of the Gammaproteobacteria recorded at Divar are classified under the order Chromatiales, Alteromonadales and 
Oceanospirillales. Species belonging to the genus Marinobacter, Shewanella, Alteromonas of order Alteromonadales have been commonly found in the marine environment (Zhuang et al., 2009). These genera have also been recorded in the present investigation. Marinobacter spp. use a variety of hydrocarbons as the sole source of carbon and energy (Gauthier et al., 1992). These halophilic bacteria also have a high capacity for denitrification (Yoshie et al., 2006). Similarly, Shewanella (Brettar et al., 2002; Zhao et al., 2006) and Alteromonas(Haijun, 2002) are known to mediate the reductive phase of the $\mathrm{N}$ cycle. In the present study, denitrification, a key process in the nitrogen cycle, was examined. At the time of sampling, near fresh water conditions prevailed in the mangrove systems as a result of rainfall over the region which was evident from low salinity values of $\leq 1 \mathrm{psu}$. The Divar ecosystem is prone to high external nutrient input due to land runoff during the monsoon (Divya et al., 2009). As expected, pore water analysis in the present study revealed higher concentration of inorganic nitrogenous compounds and organic carbon content at Divar. Denitrification activity was also found to be significantly higher at Divar as compared to Tuvem providing evidence for the active occurrence of alternate respiratory pathways which consequently help to reduce the nutrient load in the aquatic system. Further, degradative pathways like denitrification also result in the oxidation of organic matter. The Divar sediments are organic carbon rich and the existence of metabolically versatile bacteria could indicate their contribution to the $\mathrm{C}$ and $\mathrm{N}$ cycle. Fast growing Gammaproteobacteria dominate estuaries (Greer, 2010) and they have a preference for elevated concentrations of nutrients (Pinhassi and Berman, 2003). The Gammaproteobacteria form the most abundant denitrifying communities in marine sediments (Bhatt et al., 2005). About $96 \%$ of cultured denitrifiers belong to the Gammaproteobacteria (Brettar et al., 2002). The culturable and non-culturable (probed based on the phylogenetic diversity of nos $Z$ genes) denitrifiers from Tuvem and Divar mostly belong to the class Gammaproteobacteria (Fernandes, 2010; Fernandes et al., 2012). Nitrification has also been reported to occur at the same sampling locations and has been found to be mediated by bacteria belonging to the Beta and Gammaproteobacteria (Krishnan, 2010). The pyrosequencing approach has revealed a low abundance of nitrifying Betaproteobacteria-related phylotypes. An abundance of sulfide-oxidizing denitrifiers (class Gammaproteobacteria, order Chromatiales) has also been observed (Mori et al., 2011). It is possible that the oxidative pathway of nitrogen in mangrove sediments is also more likely to be mediated by members belonging to the class Gammaproteobacteria.

Rarefaction curves at both locations did not reach an asymptotic stage indicating that the bacterial richness in the present study was not fully covered. Statistical richness estimates of Chaol and ACE indicated that species richness in mangrove sediments was less than tidal mud flats of Dongmak, Korea (Kim et al., 2008). Contrastingly, when compared to the water columns of ocean,(Kirchman et al., 2010) the species richness in mangrove sediments is far greater. A considerable fraction of the low-abundance OTUs of the so called "rare biosphere"(Sogin et al., 2006) were responsible for the high diversity observed in mangrove sediments and indicate that they have the potential to become dominant when favorable environmental conditions arise. Like in most molecular based taxonomic surveys of bacterial communities from environmental samples, a significant fraction of the bacterial population at both the locations are new as they have not been identified up to the class level. About $18 \%$ of the total tag sequences recovered at Divar and $22 \%$ at Tuvem belonging to various microbes await to be cultured and identified. These sequences have not been reported in earlier studies carried out in mangroves. It is evident that previous reports may have underestimated bacterial diversity since they incorporated tedious cloning procedures and a limited number of sequences. The Venn diagram illustrated that majority of the OTUs in the present study were specific to the sampling sites with $<35 \%$ of the sequence clusters being common between both the sites. Fewer samples in this study did not permit the use of statistical methods to assess the interrelationships between environmental characteristics and bacterial diversity. However, the largely unique bacterial community, higher inorganic-N content, DNT and predominance of clusters belonging to Gammaproteobacteria at Divar indicate that the population structure is influenced by the prevailing environmental conditions.

Though our analysis was limited to single sediment samples from two different locations, the pyrosequencing technique was useful in revealing sustenance of higher bacterial diversity and richness at the anthropogenicallyinfluenced Divar as compared to Tuvem. This finding suggests that the levels of pollutants are not a deterrent for affecting bacterial diversity at Divar. On the contrary, they could play an important role in buffering the anthropogenic influences. Higher occurrence of tag sequences associated to class Gammaproteobacteria at Divar was also observed which is suggestive of their role in lowering nitrate levels through DNT. Thus, the prevailing environmental conditions could be crucial in influencing the composition of the autochthonous benthic bacterial communities which play a vital role in ecosystem functioning. More interestingly, a significant fraction of the novel bacterial population at both the locations await to be cultured and identified for various applications. Future studies would be directed to understand the dynamics of the microbial populations at a higher spatial and temporal resolution.

\section{Acknowledgments}

The authors thank Director, NIO for the facilities. The authors are grateful to the support extended by Dr. Linda 
Amaral Zettler, Associate Research Scientist, MBL under the aegis of ICoMM. SOF is also thankful to the Council of Scientific and Industrial Research (Govt. of India) for the award of Senior Research Fellowship (2006-09) and Research Associateship (2011). This is NIO contribution no. 5609.

\section{References}

Adinarayana G, Venkateshan MR, Bapiraju VV, Sujatha P, Premkumar J, Ellaiah P, Zeeck A (2006) Cytotoxic compounds from the marine actinobacterium. Bioorg khim 32:328-334.

Alongi DM, Boto KG, Tirendi F (1989) Effect of exported mangrove litter on bacterial productivity and dissolved organic carbon fluxes in adjacent tropical nearshore sediments. Mar Ecol Prog Ser 56:133-144.

Andersson AF, Riemann L, Bertilsson S (2010) Pyrosequencing reveals contrasting seasonal dynamics of taxa within Baltic Sea bacterioplankton communities. ISME J 4:171-181.

Ansari ZA, Ingole BS, Parulekar AH (1986) Effect of high organic enrichment of benthic polychaete population in an estuary. Mar Pollut Bull 17:361-365.

Attri K, Kerkar S, LokaBharathi PA (2011) Ambient iron concentration regulates the sulfate reducing activity in the mangrove swamps of Diwar, Goa, India. Estuar Coast Shelf Sci 95:156-164.

Bendschneider K, Robinson NJ (1952) A new spectrophotometric determination of nitrite in seawater. J Mar Res 11:87-96.

Bhatt M, Zhao JS, Monteil-Rivera F, Hawari M (2005) Biodegradation of cyclic nitramines by tropical marine sediment bacteria. J Ind Microbiol Biot 32:261-267.

Bonin P, Tamburini C, Michotey V (2002) Determination of bacterial processes which are sources of nitrous oxide production in marine samples. Water Res 36:722-732.

Bowman JP, McCammon SA, Dann AL (2005) Biogeographic and quantitative analyses of abundant uncultivated gammaproteobacterial clades from marine sediment. Microbial Ecol 49:451-60.

Brettar I, Christen R, Höfle M (2002) Shewanella denitrificans sp. nov., a vigorously denitrifying bacterium isolated from the oxic-anoxic interface of the Gotland Deep in the central Baltic Sea. Int J Syst Evol Microbiol 52:2211-2217.

Bryan CG, Johnson DB (2008) Dissimilatory ferrous iron oxidation at a low $\mathrm{pH}$ : a novel trait identified in the bacterial subclass Rubrobacteridae. FEMS Microbiol Lett 228:149-155.

Chao A (1987) Estimating the population-size for capture recapture data with unequal catchability. Biometrics 43:783-791.

Chao A, Lee SM (1992) Estimating the number of classes via sample coverage. J Am Statist Assoc 87:210-217.

Chariton AA, Court LN, Hartley DM Colloff MJ, Hardy CM (2010) Ecological assessment of estuarine sediments by pyrosequencing eukaryotic ribosomal DNA. Front Ecol Environ 8:233-238.

De Souza SN (1999) Effect of mining rejects on the nutrient chemistry of Mandovi estuary, Goa. Indian J Mar Sci 28:198-210.

Divya B, Fernandes SO, Sheelu G, Nair S, LokaBharathi PA, Chandramohan D (2009) Limnotolerant bacteria govern nitrate concentration in Mandovi estuary, India. Estuar Coast Shelf Sci 82:29-34.
Dos Santos HF, Cury JC, do Carmo FL, dos Santos AL, Tiedje J, van Elsas JD, Rosado AS, Peixoto RS (2011) Mangrove bacterial diversity and the impact of oil contamination revealed by pyrosequencing: Bacterial proxies for oil pollution. PLoS One 6:e16943.

Ellaiah P, Zeeck A(2006) Cytotoxic compounds from the marine actinobacterium Streptomyces corchorusii $\mathrm{AUBN}_{1} / 7^{1}$. Bioorg khim 32:295-300.

El Wakeel SK, Riley JP (1957) Determination of organic carbon in the marine muds. J. Du Conseil Intrenational Pour L'exploration De La Mer 22:180-183.

Felsenstein J (2005) PHYLIP (Phylogeny Inference Package) version 3.6. Department of Genome Sciences, University of Washington, Seattle.

Fernandes SO (2010) Ecology of denitrifiers in mangrove sediments. Ph.D. Dissertation. Goa University, Goa, India.

Fernandes SO, Bonin PC, Michotey VD, LokaBharathi PA (2010) Denitrification: An important pathway for nitrous oxide production in tropical mangrove sediments (Goa, India). J Environ Qual 39:1507-1516.

Fernandes SO, LokaBharathi PA (2011) Nitrate levels modulate denitrification activity in tropical mangrove sediments (Goa, India). Environ Monit Assess 173:117-125.

Fernandes SO, Michotey VD, Guasco S, Bonin PC, LokaBharathi PA (2012) Denitrification prevails over anammox in tropical mangrove sediments (Goa, India). Mar Environ Res 74:9-19.

Gauthier MJ, Lafay B, Christen R, Fernandez L, Acquaviva M, Bonin P, Bertrand JC (1992) Marinobacter hydrcarbonoclasticus gen. nov., sp. nov., a new, extremely halotolerant, hydrocarbon degrading marine bacterium. Int J Syst Evol Microbiol 42:568-576.

Greene AC, Patel BKC, Yacob S (2009) Geoalkalibacter subterraneus sp. nov., an anaerobic Fe(III)- and $\mathrm{Mn}(\mathrm{IV})$-reducing bacterium from a petroleum reservoir, and emended descriptions of the family Desulfuromonadaceae and the genus Geoalkalibacter. Int J Syst Evol Microbiol 59:781-785.

Greer CW (2010) Bacterial diversity in hydrocarbon-polluted rivers, estuaries and sediments. In: Timmis, KN (ed) Handbook of Hydrocarbon and Lipid Microbiology. SpringerVerlag Berlin, pp 2329-2338.

Haijun X (2002) Two strains of Alteromonas putrefaciens with dye-decolouring capability. Chin J Appl Environ Biol 8:294-297.

Harwati TU, Kasai Y, Kodama Y, Susilaningsih D, Watanabe K (2007) Characterization of diverse hydrocarbon-degrading bacteria isolated from Indonesian seawater. Microb Environ 22:412-415.

Hobbie JE, Daley RJ, Jasper S (1977) Use of nucleopore filters for counting bacteria by fluorescence microscopy. Appl Environ Microb 33:1225-1228.

Hu Q, Qi H, Zeng J, Zhang H (2007) Bacterial diversity in soils around a lead and zinc mine. J Environ Sci 19:74-79.

Huber JA, Welch DBM, Morrison HG, Huse SM, Neal PR, Butterfield DA, Sogin ML (2007) Microbial population structures in the deep marine biosphere. Science 318:97100.

Hunter EM, Mills HJ, Kostka JE(2006) Microbial community diversity associated with carbon and nitrogen cycling in permeable shelf sediments. Appl Environ Microb 72:56895701 . 
Huse SM, Huber J, Morrison H, Sogin M, Welch D (2007) Accuracy and quality of massively parallel DNA pyrosequencing. Genome Biol 8:R143.

Huse SM, Dethlefsen L, Huber JA, Welch DM, Relman DA, Sogin ML (2008) Exploring microbial diversity and taxonomy using SSU rRNA hypervariable tag sequencing. PLoS Genet 4:1-10.

Johnson DB, Bacelar-Nicolau P, Okibe N, Thomas A, Hallberg KB (2009) Ferrimicrobium acidiphilum gen. nov., sp. nov. and Ferrithrix thermotolerans gen. nov., sp. nov.: heterotrophic, iron-oxidizing, extremely acidophilic actinobacteria. Int J Syst Evol Microbiol 59:1082-1089.

Kim TK, Hewavitharana AK, Shaw NP, Fuerst JA (2006) Discovery of a new source of rifamycin antibiotics in marine sponge Actinobacteria by phylogenetic prediction. Appl Environ Microb 72:2118-2125.

Kim BS, Kim BK, Lee JH, Kim M, Lim YW, Chun J (2008) Rapid phylogenetic dissection of prokaryotic community structure in tidal flat using pyrosequencing. J Microbiol 46:357-363.

Kirchman DL, Cottrell MT, Lovejoy C (2010) The structure of bacterial communities in the western Arctic Ocean as revealed by pyrosequencing of 16SrRNA genes. Environ Microbiol 12:1132-1143.

Kirkpatrick J, Oakley B, Fuchsman C, Srinivasan S, Staley JT, Murray JW (2006) Diversity and distribution of Planctomycetes and related bacteria in the suboxic zone of the Black Sea. Appl Environ Microb 72:3079-3083.

Koroleff F (1969) Direct determination of ammonia in natural waters as indophenol blue. ICES C.M. 1969/C: 9. Hydrol Commun p. 4.

Krishnan KP (2010) Benthic nitrification in mangrove ecosystems. Ph.D. Dissertation. Goa University, Goa, India.

Krishnan KP, Fernandes SO, Chandan GS, LokaBharathi PA (2007) Bacterial contribution to mitigation of iron and manganese in mangrove sediments. Mar Pollut Bull 54:14271433.

Krishnan KP, LokaBharathi PA (2009) Organic carbon and iron modulate nitrification rates in mangrove swamps of Goa, South west coast of India. Estuar Coast Shelf Sci 84:419426.

Li S, Xiao X, Yin X, Wang F (2006) Bacterial community along a historic lake sediment core of Ardley Island, west Antarctica. Extremophiles 10:461-467.

Liang JB, Chen YQ, Lan CY, Tam NFY, Zan QJ, Huang LN (2007) Recovery of novel bacterial diversity from mangrove sediment. Mar Biol 150:739-747.

LokaBharathi PA, Oak S, Chandramohan D (1991) Sulfatereducing bacteria from mangrove swamps. II. Their ecology and physiology. Oceanol Acta 14:163-171.

Manivasagan P, Gnanam S, Sivakumar K, Thangaradjou T (2009) Antimicrobial and cytotoxic activities of an Actinobacteria (Streptomyces Sp. PM-32) isolated from offshore sediments of the Bay of Bengal in Tamil Nadu. Adv Biol Res 3:231236.

Marcial Gomes NC, Borges LR, Paranhos R, Pinto FN, Mendonça-Hagler LCS, Smalla K (2008) Exploring the diversity of bacterial communities in sediments of urban mangrove forests. FEMS Microbiol Ecol 66:96-109.

Mori K, Suzuki K, Urabe T, Sugihara M, Tanaka K, Hamada M, Hanada S (2011) Thioprofundum hispidum sp. nov., an obligately chemolithoautotrophic sulfur-oxidizing gamma- proteobacterium isolated from the hydrothermal field on Suiyo Seamount, and proposal of Thioalkalispiraceae fam. nov. in the order Chromatiales. Int J Syst Evol Microbiol 61:2412-2418.

Paisse S, Coulon F, Goñi-Urriza M, Peperzak L, McGenity TJ, Duran R (2008) Structure of bacterial communities along a hydrocarbon contamination gradient in coastal sediment. FEMS Microbiol Ecol 66:295-305.

Pankratov TA, Dedysh SN, Zavarzin GA (2006) The leading role of actinobacteria in aerobic cellulose degradation in Sphagnum peat bogs. Dokl Biol Sci 410:428-430.

Pinhassi J, Berman T (2003) Differential growth response of colony-forming $\alpha$ - and $\gamma$ - Proteobacteria in dilution culture and nutrient addition experiments from lake Kinneret (Israel), the eastern mediterranean sea, and the Gulf of Eilat. Appl Environ Microb 69:199-211.

Qu JH, Yuan HL, Wang ET, Li C, Huang HZ (2008) Bacterial diversity in sediments of the eutrophic Guanting Reservoir, China, estimated by analyses of $16 \mathrm{~S}$ rDNA sequence. Biodivers Conserv 17:1667-1683.

R Development Core Team (2007) R: A language and environment for statistical computing. R Foundation for Statistical Computing, Vienna, Austria.

Reed AJ, Dorn R, Van Dover CL, Lutz RA, Vetriani C (2009) Phylogenetic diversity of methanogenic, sulfate-reducing and methanotrophic prokaryotes from deep-sea hydrothermal vents and cold seeps. Deep-Sea Res (Part II: Topical Studies in Oceanography) 56:1665-1674.

Roesch LFW, Fulthorpe RR, Riva A, Casella G, Hadwin AKM, Kent AD, Daroub SH, Camargo FAO, Farmerie WG, Triplett EW (2007) Pyrosequencing enumerates and contrasts soil microbial diversity. ISME J 1:283-290.

Sardessai S, Sundar D (2007) Variability of nitrate and phosphate. In: Shetye SR, Dileep Kumar M, Shankar D (eds) The Mandovi and Zuari Estuaries. National Institute of Oceanography, India, pp 59-66.

Schloss PD, Handelsman J (2005) Introducing DOTUR, a computer program for defining operational taxonomic units and estimating species richness. Appl Environ Microb 71:15011506.

Schwarz JIK, Eckert W, Conrad R (2007) Community structure of Archaea and Bacteria in a profundal lake sediment Lake Kinneret (Israel). Syst Appl Microbiol 30:239-254.

Sjöling S, Mohammed SM, Lyimo TJ, Kyazuri JJ(2005) Benthic bacterial diversity and nutrient processes in mangroves: impact of deforestation. Estuar Coast Shelf Sci 63:397-406.

Sogin ML, Morrison HG, Huber JA, Welch DM, Huse SM, Neal PR, Arrieta JM, Herndl GJ (2006) Microbial diversity in the deep sea and the underexplored "rare biosphere". Proc Natl Acad Sci USA 103:12115-12120.

Sørensen J (1978) Denitrification rates in marine sediment as measured by the acetylene inhibition technique. Appl Environ Microb 36:139-143.

Thorsten D, José LR (2001) Do mangroves rather than rivers provide nutrients to coastal environments south of the Amazon River? Evidence from long-term flux measurements. Mar Ecol Prog Ser 213:67-77.

Tiedje JM (1982) Denitrification. In: Page AL (ed) Methods of Soil Analysis, Part 2. ASA-SSSA, Madison, pp 1011-1026. 
Van Keulen G, Alderson J, White J, Sawers RG (2005) Nitrate respiration in the actinomycete Streptomyces coelicolor. Biochem Soc Trans 33:210-212.

Vrionis HA, Anderson RT, Ortiz-Bernad I, O’Neill KR, Resch CT, Peacock AD, Dayvault R, White DC, Long PE, Lovley DR (2005) Microbiological and geochemical heterogeneity in an in situ uranium bioremediation field site. Appl Environ Microb 71:6308-6318.

Ward AC, Bora N (2006) Diversity and biogeography of marine Actinobacteria. Curr Opin Microbiol 9:279-286.

Weiss RF, Price BA (1980) Nitrous oxide solubility in water and seawater. Mar Chem 8:347-359.

Wood ED, Armstrong FAJ, Richards FA (1967) Determination of nitrate in sea water by cadmium-copper reduction to nitrite. $\mathrm{J}$ Mar Biol Assoc UK 47:23-31.

Yoshie S, Ogawa T, Makino H, Hirosawa H, Tsuneda S, Hirata A (2006) Characteristics of bacteria showing high denitrification activity in saline wastewater. Lett Appl Microbiol 42:277-283.

Zhang W, Song L, Ki JS, Lau CK, Li XD, Qian PY (2008) Microbial diversity in polluted harbor sediments II: Sulfate- reducing bacterial community assessment using terminal restriction fragment length polymorphism and clone library of $d s r A B$ gene. Estuar Coast Shelf Sci 73:668-681.

Zhang Y, Dong J, Yang B, Ling J, Wang Y, Zhang S (2009) Bacterial community structure of mangrove sediments in relation to environmental variables accessed by $16 \mathrm{~S}$ rRNA gene-denaturing gradient gel electrophoresis fingerprinting. Sci Mar 73:487-498.

Zhao JS, Manno D, Leggiadro C, O’Neil D, Hawari J (2006) Shewanella halifaxensis sp. nov., a novel obligately respiratory and denitrifying psychrophile. Int J Syst Evol Microbiol 56:205-212.

Zhao J, Zeng RY (2008) Bacterial community in deep subseafloor sediments from the western Pacific "warm pool". Sci China Ser D-Earth Sc 51:618-624.

Zhuang DC, Chen YG, Zhang YQ, Tang SK, Wu XL, Tan ZC, Li WJ, Cui XL (2009) Marinobacter zhanjiangensis sp. nov., a marine bacterium isolated from sea water of a tidal flat of the South China Sea. Anton Leeuw Int J G 96:295-301.

All the content of the journal, except where otherwise noted, is licensed under a Creative Commons License CC BY-NC. 